\title{
Dendritic Cells Produce CXCL13 and Participate in the Development of Murine Small Intestine Lymphoid
} Tissues

Keely G. McDonald, Jacquelyn S. McDonough, Brian K. Dieckgraefe, and Rodney D. Newberry

From the Department of Internal Medicine, Washington

University School of Medicine, St. Louis, Missouri

In the adult intestine, luminal microbiota induce cryptopatches to transform into isolated lymphoid follicles (ILFs), which subsequently act as sites for the generation of IgA responses. The events leading to this conversion are incompletely understood. Dendritic cells (DCs) are components of cryptopatches (CPs) and ILFs and were therefore evaluated in this process. We observed that the adult murine intestine contains clusters of DCs restricted to the CP/ILF continuum. A numerical and cell associative hierarchy in the adult intestine and a chronologic hierarchy in the neonatal intestine demonstrated that these clusters form after the coalescence of $\mathrm{CD}^{+} \mathrm{O}^{+}$cells to form $\mathrm{CPs}$ and before the influx of $\mathrm{B220}^{+} \mathrm{B}$ lymphocytes to form ILFs. Cluster formation was dependent on lymphotoxin and the lymphotoxin $\beta$ receptor and independent of lymphocytes. The ILF DC population was distinguished from that of the lamina propria by the absence of $\mathrm{CD}^{+} \mathrm{CDN1c}^{+}$cells and an increased proportion of $\mathrm{CD11c}^{+} \mathrm{B220}^{+}$cells. The formation of clusters was not limited by DC numbers but was induced by luminal microbiota. Moreover, in the absence of the chemokine CXCL13, CP transformation into ILF was arrested. Furthermore, ILF DCs express CXCL13, and depletion of DCs resulted in regression of ILFs and disorganization of CPs. These results reveal DC participation in ILF transformation and maintenance and suggest that in part this may be due to CXCL13 production by these cells. (Am J Pathol 2010, 176:2367-2377; DOI: 10.2353/ajpath.2010.090723)

The mucosal immune system is charged with the task of protecting a vast environmentally exposed surface from potential pathogens. To accomplish this feat, the mucosal immune system uses a variety of strategies using aspects of both the innate and adaptive immune system; principal among these in the intestine is the production and secretion of IgA. ${ }^{1}$ Solitary intestinal lymphoid tissues (SILTs) are recently appreciated participants in this process and can function as sites for the generation of $T$ cell-dependent and T cell-independent IgA., ${ }^{2,3}$ SILT encompasses a spectrum ranging from nascent lymphoid tissues, or cryptopatches (CPs), to their more developed descendants containing lymphocytes, isolated lymphoid follicles (ILFs). ${ }^{4} \mathrm{CP}$ development and their subsequent progression to ILFs recapitulate secondary lymphoid tissue development; however, unlike secondary lymphoid tissues, which are fully formed from birth, CPS and ILFs have a plasticity that allows the transition of CPs into ILFs, and their subsequent regression back to CPs, throughout life in response to changes in local stimuli including changes in the luminal microbiota. ${ }^{5-9} \mathrm{LFF}$, but not CP, contribute to mucosal protection by acting as sites for the initiation IgA responses, which can subsequently alter the intestinal flora to return to the homeostatic state. ${ }^{5,9} \mathrm{Ac}$ cordingly, understanding how CPs transform into ILFs is central to understanding how the mucosal immune system functions to manage the luminal microbiota and protect from potential pathogens.

Our understanding of the transitioning of CP into ILFs is an evolving area. CPs are groups of lineage marker (lin) ${ }^{-}, \mathrm{c}^{-\mathrm{kit}^{+}}, \mathrm{CD}^{+} \mathrm{O}^{+}$cells clustered at the base of villi, whereas their descendents, ILFs, are more developed and organized lymphoid tissues containing lymphocytes. ${ }^{4,10-12}$ The lin $^{-} \mathrm{C}-\mathrm{kit}^{+} \mathrm{CP}$ cells share many properties with fetal lymphoid tissue inducer (LTi) cells, including cell surface molecule expression and a requirement for the transcription factor ROR $\gamma$ t in their development. ${ }^{12-14}$ Like fetal LTi cells, these CP cells mediate the

Supported by National Institutes of Health (grants DK64798 and AG028309). The Siteman Cancer Center is supported in part by a National Cancer Institute Cancer Center support grant (P30 CA91842). The Digestive Diseases Research Core Center is supported by grant P30-DK52574.

Accepted for publication January 19, 2010

Address reprint requests to Rodney D. Newberry, M.D., 660 S. Euclid Avenue, Box 8124, St. Louis, MO 63110. E-mail: rnewberry@im.wustl.edu. 
early steps of lymphoid tissue genesis by delivering a lymphotoxin (LT) signal to LT $\beta$ receptor (LT $\beta R$ ) expressing stromal cells resulting in a self-sustaining cluster, or CP. ${ }^{2,12}$ Studies suggest that unlike ILFs, the numbers of $\mathrm{CPs}$ remain relatively constant in response to changes in microbiota. ${ }^{5,8}$ Although it is clear that CPs can transition into ILFs, that this process is driven by local stimuli, and that ILFs can contribute to mucosal immunity by acting as sites for IgA production, the cellular events and molecular pathways relevant for this transition are relatively unexplored. Cell type-specific signals have been identified to play a role in ILF development. ${ }^{15-18}$ However, these signals specific for ILF development are delivered by $B$ lymphocytes or expressed by B lymphocytes, which define the presence of ILFs and are intimately involved in the process of IgA production. Therefore, it is difficult to assess a role for these signals in ILF transitioning as opposed to other aspects of ILF function. To this end, we investigated a role for dendritic cells (DCs) in ILF development. DCs have been observed to be a component of both CPs and ILFs, and therefore, understanding the role of DC in this process could provide insight into the steps linking CPs to ILFs.

Here we identify the presence of DC clusters distributed throughout the adult murine intestine. In normal animals, these DC clusters occur exclusively as part of the continuum of CPs and ILFs and are less numerous than CPs and more numerous than ILFs. Studies of the neonatal intestine revealed that the formation of these clusters occurs after the coalescence of $\mathrm{CD}^{+}{ }^{+} \mathrm{c}-\mathrm{kit}^{+}$ cells, to form CPs, and before the influx of $\mathrm{B}^{2} 2 \mathrm{O}^{+}$cells, to form ILFs. Moreover, studies of genetically manipulated animals revealed that the formation of these DC clusters is dependent on the $L T$ and $L T \beta R$ signals required for $C P$ development and independent of the presence of lymphocytes. We observed that DC cluster formation was not limited by DC numbers, and recruitment of DCs to the developing CP/ILF to form clusters was driven by changes in the luminal microbiota. Consistent with an active role for DCs in this process, we observed that deletion of DCs results in the loss of ILFs and the disorganization of CPs. Recent studies demonstrated CXCR5, the receptor for the chemokine CXCL13, plays a role in recruiting $B$ cells to developing ILFS. ${ }^{18}$ We found that ILF DCs are sources of CXCL13. Taken together, these findings demonstrate that DCs provide a link between CPs and ILFs and that the transitioning of CPs into ILFs occurs in part due to the recruitment of DCs, which produce CXCL13.

\section{Materials and Methods}

\section{Mice and Treatments}

Mice used for this study were housed in a specific-pathogen free facility and fed routine chow diet. Animal procedures and protocols were performed in accordance with the institutional review board at Washington University School of Medicine (St. Louis, MO). C57BL/6 mice, RAGdeficient mice on the $\mathrm{C} 57 \mathrm{BL} / 6$ background, transgenic mice expressing the diphtheria toxin (DT) receptor under the control of the CD11c promoter (CD11c-DTR), and CXCL13-deficient mice were purchased from The Jackson Laboratory (Bar Harbor, ME). LT $\alpha$-deficient mice, a gift from Dr. D. Chaplin (University of Alabama Birmingham, Birmingham, AL) were bred onto the C57BL/6 background for $>10$ generations before use in experiments. LT $\beta$ R-deficient mice on the C57BL/6 background were a gift from Dr. K. Pfeffer (Technical University of Munich, Munich, Germany).

$\mathrm{LT} \beta \mathrm{R}$-Ig production and treatment was performed as described previously. ${ }^{19}$ Progeny receiving $L T \beta R$-Ig in utero was analyzed at $\geq 12$ weeks of age.

PEGylated recombinant murine granulocyte-macrophage colony-stimulating factor (GM-CSF) was produced as described previously. ${ }^{20}$ Recombinant murine Fms-like tyrosine kinase 3 ligand (Flt3L) fused to the FC region of human $\operatorname{lgG}_{1}$ (Flt3L-lg) was purified via protein $G$ affinity chromatography from supernatants generated by a Flt3LIg-producing J558L cell line (generous gift from Dr. M. Colonna, Washington University). The activity of the recombinant Flt3L-Ig was confirmed by its ability to differentiate bone marrow derived DCs as described previously. ${ }^{21}$ Seven- to 10-week-old C57BL/6 mice were injected i.p. daily with $5 \mu \mathrm{g}$ of recombinant PEGylated murine GM-CSF, PBS, $20 \mu \mathrm{g}$ of recombinant murine Flt3L-Ig, or $100 \mu \mathrm{g}$ of human IgG (Bayer, Elkhart, IN). After 14 days, mice were sacrificed, and intestines were analyzed.

Gnotobiotic C57BL/6 mice were provided by Digestive Disease Research Core Center Murine Models Facility at Washington University School of Medicine. Gnotobiotic mice were conventionalized by exposure to cecal contents from conventionally housed C57BL/6 mice as described previously. ${ }^{7}$ At the time of sacrifice, cecal cultures from gnotobiotic mice were obtained to confirm the absence of bacterial flora.

Seven- to 10-week-old CD11c-DTR mice or nontransgenic littermates were injected i.p. with $4 \mathrm{ng} / \mathrm{g}$ body weight of DT (Sigma-Aldrich, St. Louis, MO) on day 0 and with 2 ng/g body weight of DT 24 hours later on day 1. Groups of mice were analyzed on day 1 for the presence of intestinal DCs by flow cytometry and whole mounts, and on day 2 for the presence of $\mathrm{B}^{2} 2 \mathrm{O}^{+}$clusters and $\mathrm{CD}^{+}$clusters.

\section{Whole Mounts and Immunohistochemistry}

Whole mounts of the adult small intestine were performed as described previously. ${ }^{7}$ To evaluate the neonatal intestine by whole mount, the intestine was mounted with the serosal side facing up, and standard immunohistochemistry was performed. Tissues were examined under a dissecting microscope at $\times 65$ and were mounted on glass slides as 4-cm segments and examined under an upright light or fluorescent microscope at 100 to $400 \mathrm{X}$ magnification. Well-developed lymphoid tissues falling on the antimesenteric border of neonatal small intestine were considered PPs and, consequently, excluded from the analysis.

For immunohistochemistry, intestines were embedded in optimal cutting temperature compound (Sakura Fi- 
netek, Torrence, CA), frozen, and serial 8- $\mu \mathrm{m}$ sections were cut at an axis perpendicular to the villi for the evaluation of $\mathrm{CD}_{11 \mathrm{c}^{+}}$clusters. Staining of frozen sections was performed as described previously. ${ }^{16}$ Pseudocolored black-and-white images from fluorescent microscopy were obtained with an Axioskop 2 microscope using Axiovision software (Carl Zeiss Microlmaging, Thornwood, NY).

To detect CXCL13 in tissues, mice were perfused with cold PBS, followed by $4 \%$ paraformaldehyde. Intestines were removed and incubated in a solution of $4 \%$ paraformaldehyde and $2 \%$ sucrose for 30 minutes, embedded in optimal cutting temperature compound, and frozen, and serial $8-\mu \mathrm{m}$ sections of intestine were obtained. To detect CXCL13 in single cells, ILF cellular populations were isolated as previously described ${ }^{16}$ and adhered to ImmunoSelect adhesion slides (MoBiTec, Göttingen, Germany), and immunohistochemistry was performed. CXCL13 was detected with a polyclonal rabbit antimouse CXCL13 antibody (eBioscience, San Diego, CA) using biotinylated goat anti-rabbit secondary antibody and streptavidin-conjugated cyanine 3 (Jackson ImmunoResearch Laboratories, West Grove, PA).

\section{Flow Cytometric Analysis}

ILF cellular populations were isolated from C57BL/6 mice receiving $L T \beta R$-Ig in utero, and lamina propria $(L P)$ cellular populations, not including PP, were isolated as described previously. ${ }^{16}$ To release DCs, ILF cellular populations were incubated with $20 \mathrm{U} / \mathrm{ml}$ collagenase type VIII (Sigma-Aldrich) in RPMI 1640 medium (BioWhittaker, Walkersville, MD) containing $2 \mathrm{mmol} / \mathrm{L}$ Glutamax I (Lalanyl-L-glutamine; Invitrogen Life Technologies, Carlsbad, CA), $1 \mathrm{mmol} / \mathrm{L}$ sodium pyruvate, $5 \%$ calf serum (HyClone, Logan, UT), 0.05 mmol/L 2-mercaptoethanol, nonessential amino acids (Invitrogen Life Technologies), and sodium bicarbonate (Invitrogen Life Technologies) at $37^{\circ} \mathrm{C}$ with shaking for 15 minutes. ILF cellular populations were incubated with HBSS (BioWhittaker) containing 5 $\mathrm{mmol} / \mathrm{L}$ EDTA at $37^{\circ} \mathrm{C}$ with shaking for 10 minutes and washed with PBS before staining for flow cytometry. ILF cellular populations from multiple mice were pooled for analysis. LP cellular populations from individual mice were isolated as previously described ${ }^{19}$ and analyzed. Forward scatter, side scatter, and the incorporation of 7-aminoactinomycin D were used to gate out dead cells. Remaining events were analyzed in four channels using a FACScan cytometer (BD Biosciences, San Jose, CA) retrofitted with a second laser. Data acquisition was performed using CellQuest (BD Biosciences) and Rainbow (Cytek, Fremont, CA) software. Data analysis was performed on a Macintosh G4 computer running FlowJo software (Tree Star, Ashland, OR). Antibodies used for analysis included anti-mouse CD11c (BD Biosciences), anti-mouse $\mathrm{CD} 4$, anti-mouse $\mathrm{CD} 8 \alpha$, anti-mouse CD11b, anti-mouse B220, and appropriate isotype controls (all from eBioscience).

\section{Real-Time PCR}

ILF cellular populations were isolated from C57BL/6 mice treated with LT $\beta$ R-Ig in utero as described above. $\mathrm{CD}_{11 \mathrm{C}^{+}}$and $\mathrm{CD}^{-11 \mathrm{C}^{-}}$cells were isolated using antiCD11c microbeads (Miltenyi Biotec, Auburn, CA) following the manufacturers recommendation, RNA was isolated treated with DNase and transcribed into cDNA. The following primers were used: 18s, forward, 5'-CGGCTACCACATCCAAGGAA-3', and reverse, 5'-GCTGGAATTACCGCGGCT-3'; and CXCL13, forward, 5'-CAGAATGAGGCTCAGCACAGC-3', and reverse 5'-CAGAATACCGTGGCCTGGAG-3'. To construct a standard, RNA was isolated from the spleen of C57BL/6 mice, transcribed into CDNA, and used to generate a PCR product that was cloned using the pCRII-TOPO vector and cloning kit (Invitrogen Life Technologies) per the manufacturer's instructions.

\section{Statistical Analysis}

Data analysis using a Student's t-test and a one-way analysis of variance with a Tukey's posttest was performed using GraphPad Prism (GraphPad Software, San Diego, CA).

\section{Results}

\section{The Adult Murine Small Intestine Contains Discreet Clusters of DCs That Are Components of the of CP/ILF Spectrum}

To evaluate the regional distribution and macroscopic and microscopic organization of intestinal DCs, we examined intestinal whole mounts stained with anti-CD11c, a widely used marker to identify murine DCs. ${ }^{22}$ Whole mounts of the small intestine revealed discreet clusters of DCs located at the base of the villi (Figure 1, A and B). To evaluate the association of these $\mathrm{CD}_{11 \mathrm{C}^{+}}$cellular clusters with components of the CP/ILF spectrum, we performed immunhistochemistry to colocalize the CD11 $\mathrm{c}^{+}$ clusters with the $\mathrm{CD}^{+}{ }^{+}$clusters of $\mathrm{CP}$ cells and the $\mathrm{B}^{2} 20^{+}$clusters identifying ILFs. Multicolor immunohistochemistry revealed that all of the $\mathrm{CD} 11 \mathrm{C}^{+}$cellular clusters colocalized with $\mathrm{CD}^{+}{ }^{+}$cellular clusters (Figure 1C). The $\mathrm{CD}^{+}$clusters were also c-kit ${ }^{+}$(data not shown). B220 ${ }^{+}$cells were found to be absent from some $\mathrm{CD}_{11 \mathrm{C}^{+}}$cellular clusters and present in others (Figure 1, D-E). Consistent with the above observations implying that the CD11C ${ }^{+}$clusters could identify an intermediate stage of CPs developing into ILFs, ${\mathrm{CD} 11 \mathrm{C}^{+}}^{+}$clusters were more numerous than ${\mathrm{B} 220^{+}}^{+}$ clusters but shared a similar distribution within the small intestine (Figure 1G). Moreover, we observed that the formation of the $\mathrm{CD} 11 \mathrm{C}^{+}$clusters was unaffected in $\mathrm{RAG}^{-1-}$ mice and therefore independent of $\mathrm{B}$ lymphocytes (Figure $1 \mathrm{H}$ ), which enter SILTs late in the process of CPs transforming into ILFs, and play impor- 

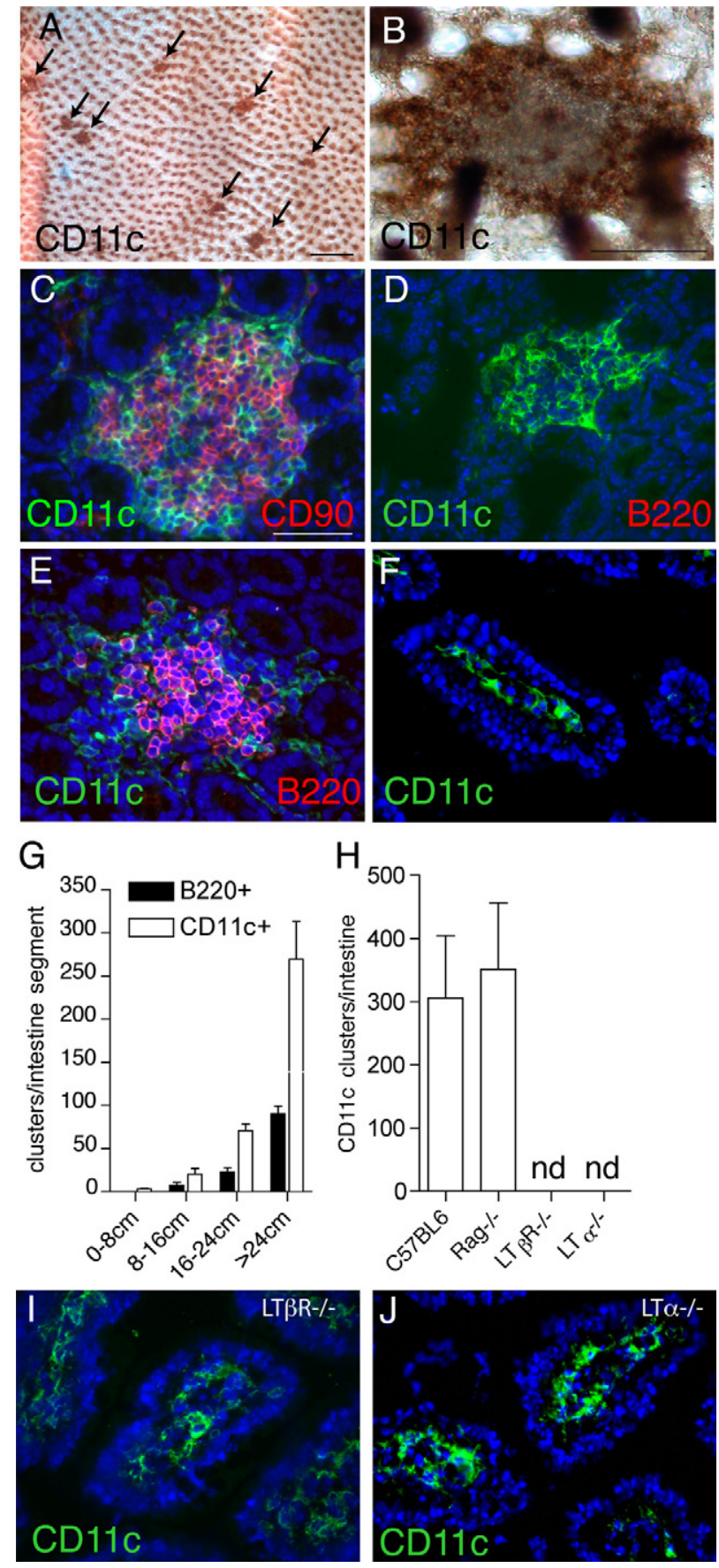

Figure 1. Intestinal DCs form discreet clusters that are part of the CP/ILF continuum. Using anti-CD11c-stained whole mounts (brown staining, $\mathbf{A}$ and B) and traditional immunohistochemistry (green staining, $\mathbf{C}-\mathbf{F}, \mathbf{I}$, and $\mathbf{J}$ ), we evaluated the regional location, organization, and cellular associations intestinal DCs in wild-type $(\mathbf{A}-\mathbf{G})$ and genetically manipulated mice on the C57BL/ 6 background $(\mathbf{H}-\mathbf{J})$. We observed that the intestine contained multiple clusters of DCs (arrows, A), and these clusters were located at the base of villi (en face view of whole mount at higher power, B). All of the DC clusters we observed were associated with $\mathrm{CD}^{+} 0^{+}$cells $(\mathbf{C})$, consistent with their localization to $\mathrm{CP}$. The DC clusters contained variable numbers of $\mathrm{B} 220^{+}$cells; some containing no $\mathrm{B} 220^{+}$cells (D) and others colocalizing with $\mathrm{B}_{2} 20^{+}$clusters (E). DC clusters were more numerous than $\mathrm{B} 220^{+}$ clusters but had an identical regional distribution $(\mathbf{G})$. Like the formation of ILFs and CPs, the formation of DC clusters was dependent on LT and the LT $\beta R$ but independent of the presence of T or B lymphocytes $(\mathbf{H})$. However unlike the development of DC clusters, the presence of LP DCs was not dependent on LT $\alpha$ or LT $\beta$ R (I and $\mathbf{J}$ ). $n=3$ or more animals from each group for data in $\mathbf{G}$ and $\mathbf{H}$. nd = none detected. Scales bars in panels A $=500 \mu \mathrm{m}$ and in panels $\mathrm{B}$ and $\mathrm{C}=100 \mu \mathrm{m}$. tant roles in the organization of ILFs. ${ }^{15} \mathrm{CD} 11 \mathrm{C}^{+}$cluster formation was dependent on LT and the LT $\beta \mathrm{R}$, which are required for the coalescence of the $\mathrm{CD}^{+}{ }^{+}$cells to form $\mathrm{CP}^{23}$ (Figure 1H). Notably, although CD11 $\mathrm{c}^{+}$clusters were absent, we observed a prominent CD11 ${ }^{+}$ cellular population in the LP in $\mathrm{LT} \alpha^{-1-}$ and $\mathrm{LT} \beta \mathrm{R}^{-1-}$ mice (Figure $1 \mathrm{I}$ and $\mathrm{J}$ ), which resembled that seen in C57BL/6 mice (Figure 1F), thus demonstrating differential requirements for the presence of CD11 ${ }^{+}$cells in the LP and the development of CD11 ${ }^{+}$clusters.

\section{CD11C ${ }^{+}$Clusters Develop after CD90 ${ }^{+}$Clusters and before $\mathrm{B220}^{+}$Clusters in the Neonatal Intestine}

In contrast to secondary lymphoid tissues, CPs and ILFs do not form during embryogenesis but develop in the neonatal period, with CPs being first observed 14 to 17 days after birth ${ }^{11}$ and ILFs developing later, $\sim 25$ days after birth in the C57BL/6 strain. ${ }^{10}$ To evaluate the timing of $\mathrm{CD} 11 \mathrm{C}^{+}$cluster development and its relationship to CP and ILF development in the neonatal period, we evaluated intestines from neonatal C57BL/6 mice and compared the numbers of $\mathrm{CD}^{\circ} 0^{+}, \mathrm{CD} 11 \mathrm{C}^{+}$, and $\mathrm{B} 220^{+}$clusters and determined the colocalization of these cell types using multicolor immunohistochemistry. We observed that the clusters in the neonatal intestine were first observed and more prominent in the distal intestine and therefore limited our analysis to the distal one-third of the neonatal intestine. We did not find $\mathrm{CD}^{+}{ }^{+}, \mathrm{CD} 11 \mathrm{c}^{+}$, or $\mathrm{B}_{2} 20^{+}$cellular clusters corresponding to components of the CP/ILF spectrum before day 17 of life. However, we observed that CPs, as defined by clusters of $\mathrm{CD}^{+}{ }^{+} \mathrm{C}-$ $\mathrm{kit}^{+}$cells, first appeared on day 17 of life, and a few of these clusters contained $\mathrm{CD}_{11 \mathrm{C}^{+}}$cells, but none contained $\mathrm{B}^{2} 2 \mathrm{O}^{+}$cells (Figure 2, A-D). Accordingly, we observed rare $\mathrm{CD} 11 \mathrm{C}^{+}$clusters and no $\mathrm{B}_{2} 2 \mathrm{O}^{+}$clusters on day 17 of life (Figure 2A). The $\mathrm{B}^{2} 2 \mathrm{O}^{+}$clusters first appeared on day 18 of life and were infrequent (Figure 2A). We observed that on day 18 of life, some CD90 ${ }^{+}$clusters contained a few $\mathrm{B}^{2} 2 \mathrm{O}^{+}$cells and that most contained $\mathrm{CD}_{11 \mathrm{C}^{+}}$cells (Figure 2, A, E, and F). In no instance did we observe $\mathrm{CD}^{+}{ }^{+}$clusters containing $\mathrm{B}^{2} 20^{+}$cells and lacking $\mathrm{CD}_{11 \mathrm{C}^{+}}$cells. By day 19 of neonatal life, the entire complement of cellular clusters comprising the known CP/ILF spectrum was present and in proportions approximately equivalent to that seen in the adult intestine (Figure 2A). CD90 ${ }^{+}$clusters were also c-kit ${ }^{+}$(Figure 2, $F$ and $G$ ). Although $\mathrm{CD}_{11 \mathrm{C}^{+}}$clusters were rare, LP CD11C ${ }^{+}$cellular populations were prominent on neonatal day 17 (Figure $2 \mathrm{H}$ ), further demonstrating differences between the presence of CD11C ${ }^{+}$cells in the LP and the development of $\mathrm{CD}_{11 \mathrm{C}^{+}}$clusters. These observations suggest an order of entry of cell types into the developing ILFs in the neonatal period with DCs preceding B lymphocytes and are consistent with the above findings in the adult intestine. 

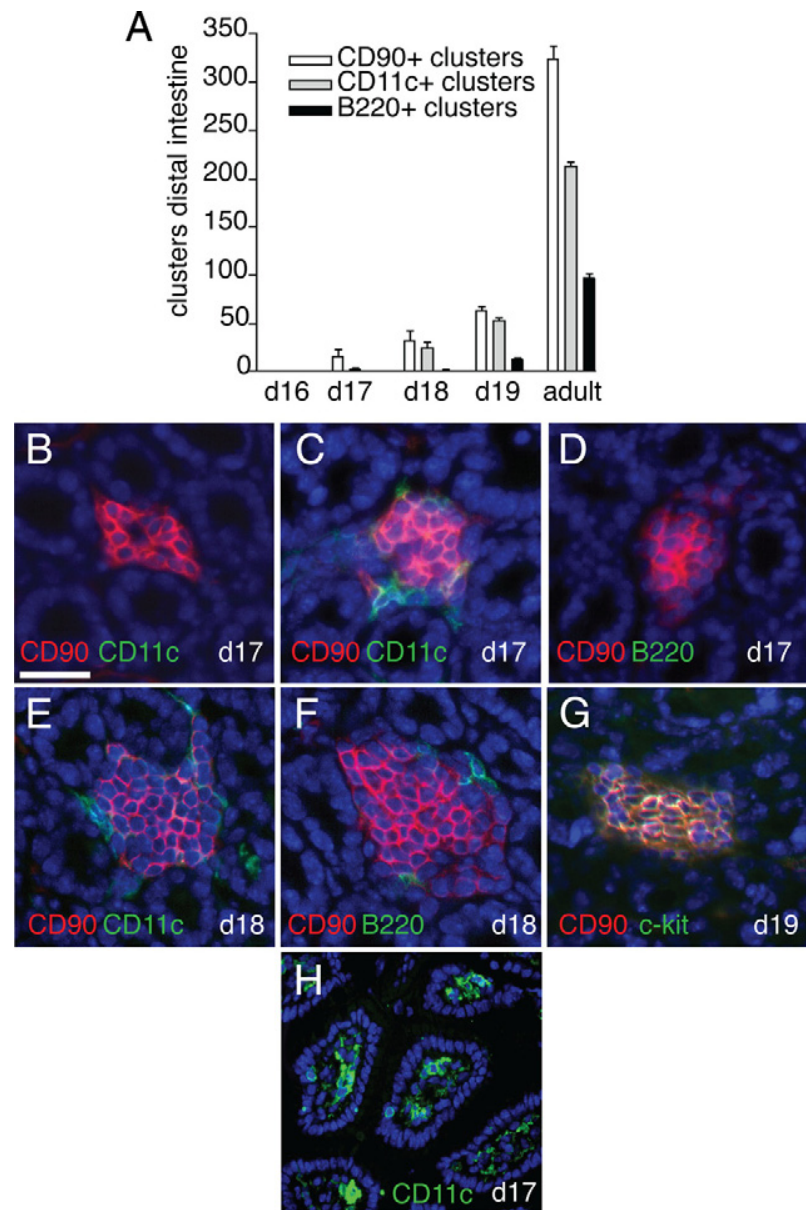

Figure 2. $\mathrm{CD}_{11 \mathrm{c}^{+}}$clusters develop after $\mathrm{CD} 90^{+}$clusters and before $\mathrm{B} 220^{+}$ clusters in the neonatal intestine. CPs and ILFs first appear in the neonatal period. To examine the chronology of cellular cluster formation in SILT development, we evaluated the presence of $\mathrm{CD} 90^{+}, \mathrm{CD}_{11 \mathrm{c}^{+}}$, or $\mathrm{B} 220^{+}$ clusters in the intestine of $\mathrm{C} 57 \mathrm{BL} / 6$ neonatal mice. None of these cellular clusters was present before day 17 of life $(\mathbf{A}) . \mathrm{CD} 90^{+}$clusters were present on day 17 of life, a few of these clusters contained CD $11 \mathrm{c}^{+}$cells, none of these clusters contained $\mathrm{B}_{22}{ }^{+}$cells $(\mathbf{A}-\mathbf{D})$. On day 18 of life, CD11c ${ }^{+}$ clusters were present and were nearly as numerous as the $\mathrm{CD} \mathrm{O}^{+}$clusters (A). In each instance the $\mathrm{CD} 11 \mathrm{c}^{+}$clusters were associated with $\mathrm{CD} 90^{+}$ clusters, and a few clusters contained $\mathrm{B} 220^{+}$cells $(\mathbf{E}$ and $\mathbf{F})$. The full complement of cellular clusters was present by day 19 of life and in proportions that approximate that seen in the adult intestine (A). All $\mathrm{CD}^{+} 0^{+}$clusters were also c-kit ${ }^{+}(\mathbf{G})$. Although DC clusters were rare, LP DC populations were readily apparent on day 17 of neonatal life $(\mathbf{H}) . n=$ 3 or more mice for each time point and type of cellular cluster in examined in A. Scale bar $=50 \mu \mathrm{m}$.

\section{The CD11C ${ }^{+}$Cell Populations from ILFs and the LP Have Different Phenotypes}

We evaluated the phenotype of the $\mathrm{CD} 11 \mathrm{c}^{+}$cells from the ILFs and compared these findings with those from DCs isolated from the diffuse LP. Because all SILTs cannot be mechanically dissociated from the LP, LP cellular populations will contain cellular components derived from SILTs. However, it is anticipated that these components will represent a minority of the LP cellular population as demonstrated by the rarity of LTi-like cells, which are significant components of SILTs, in the diffuse LP population. ${ }^{13}$ ILF CD $11 \mathrm{C}^{+}$cells were largely $\mathrm{CD} 11 \mathrm{~b}^{-}$and almost exclusively $\mathrm{CD}^{-}$, whereas those from the LP were largely $\mathrm{CD}_{11} \mathrm{~b}^{+}$and commonly $\mathrm{CD}^{+}$(Figure 3 ).
A

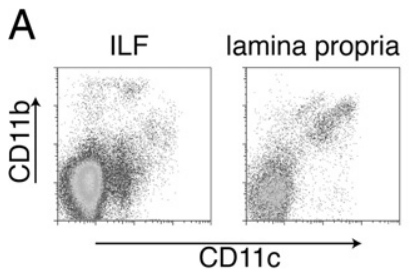

B Gated on CD11c+ cells
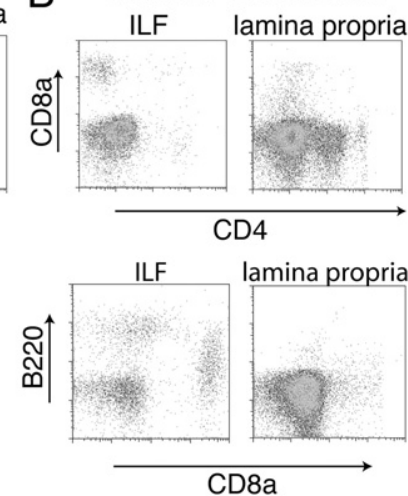
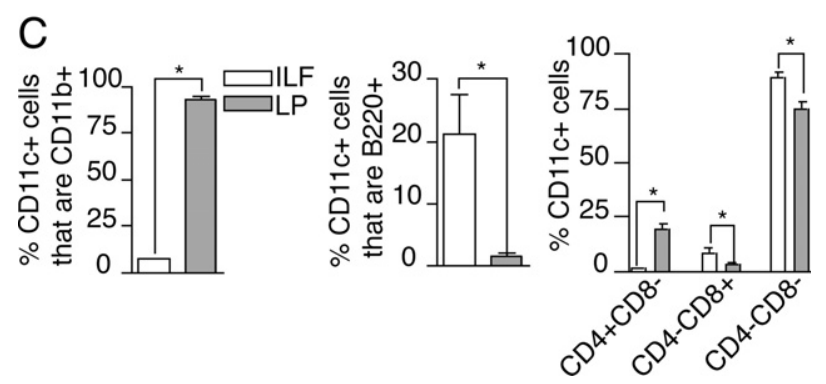

Figure 3. ILF and LP CD $11 \mathrm{c}^{+}$cell populations have different phenotypes. To compare the phenotype of $\mathrm{CD} 11 \mathrm{c}^{+}$cells located within the clusters to those located within the general LP, cellular populations were isolated from ILFs and LP and examined with multicolor flow cytometry. ILF CD $11 \mathrm{c}^{+}$cells were largely $\mathrm{CD}_{11} \mathrm{~b}^{-}$, whereas in comparison those from the LP were largely $\mathrm{CD}_{11 \mathrm{~b}^{+}}(\mathbf{A}$ and $\mathbf{C})$. The ILFs contained almost no $\mathrm{CD} 4{ }^{+} \mathrm{CD} 11 \mathrm{c}^{+}$cells, whereas this cellular population was prominent in the LP (B and $\mathbf{C})$. Conversely $\mathrm{CD} 11 \mathrm{c}^{+} \mathrm{B} 220^{+}$and $\mathrm{CD} 11 \mathrm{c}^{+} \mathrm{CD} 8 \alpha^{+}$cells were relatively enriched in ILFs when compared with the LP (B and $\mathbf{C})$. Using CD 4 and CD8 $\alpha$ expression to classify the $\mathrm{CD} 11 \mathrm{c}^{+}$cell subtypes, we observed that $\mathrm{CD} 11 \mathrm{c}^{+}$cellular population from both the LP and ILFs was predominantly CD $4^{-} \mathrm{CD} 8 \alpha^{-}$, whereas the LP population was relatively enriched in $\mathrm{CD} 4^{+} \mathrm{CD} 8 \alpha^{-}$cells, and the ILF population was relatively enriched in $\mathrm{CD}^{-} \mathrm{CD} 8 \alpha^{+}$cells $(\mathbf{C}) . n=3$ or more replicates using ILF cellular populations pooled from multiple animals and LP populations for data in $\mathbf{C} .{ }^{*} P<0.05$.

The ILF CD11 ${ }^{+}$population contained $\mathrm{CD} 8 \alpha^{+}$cells and $\mathrm{B}^{2} 2 \mathrm{O}^{+}$cells; these cell populations were less common in the LP (Figure 3, B and C). CD4 and CD8 $\alpha$ expression have been proposed to identify subtypes of DCs within lymphoid tissues. ${ }^{24}$ Using this classification, we observed that the majority of ILF and LP CD11 ${ }^{+}$cells did not express CD4 or CD8 $\alpha$; however, the LP CD $11 \mathrm{c}^{+}$cell population contained a significant proportion of $\mathrm{CD}^{+}$ $\mathrm{CD} 8 \alpha^{-}$cells, and these cells were almost completely absent from the ILFs (Figure 3C). Conversely the ILFS contained a larger population of $\mathrm{CD} 11 \mathrm{c}^{+}$cells that were $\mathrm{CD} 4^{-} \mathrm{CD} 8 \alpha^{+}$(Figure $3 \mathrm{C}$ ). These findings may be consistent with different origins of ILF and LP CD11 ${ }^{+}$cells or may be consistent with ILF CD $11 \mathrm{C}^{+}$cells arising from the $\mathrm{LP}$, because as anticipated, all ILF CD $11 \mathrm{c}^{+}$cell subtypes were present to some degree within the LP. However, the absence of $\mathrm{CD} 4^{+} \mathrm{CD} 11 \mathrm{c}+$ cells and the enrichment in $\mathrm{CD} 8 \alpha^{+} \mathrm{CD} 11 \mathrm{C}^{+}$cells and $\mathrm{B} 22 \mathrm{O}^{+} \mathrm{CD} 11 \mathrm{C}^{+}$cells suggest that if ILF CD11 ${ }^{+}$cells do arise from the LP, the process of ILF development is selective for some LP CD $11 \mathrm{C}^{+}$cell types and suggests that the formation of these CD $11 \mathrm{C}^{+}$ clusters does not occur from nonselective coalescence of the LP DC population. 
Cell Numbers are Not Limiting in the

Development of CD11 $\mathrm{C}^{+}$Clusters: The Formation of $\mathrm{CD} 11 \mathrm{c}^{+}$Clusters Can be Driven by Luminal Microbiota

It is estimated that the murine small intestine contains 1000 CPs. ${ }^{11}$ In our experience, most CPs contain a few DCs, and a minority of CPs contain a substantial number of DCs forming a distinct cluster. This observation is consistent with the availability of DCs, as opposed to a stimulus or signal as the limiting step in forming a cluster of $\mathrm{CD}_{11 \mathrm{C}^{+}}$cells. GM-CSF has the capacity to differentiate a recently identified clonogenic bone marrow progenitor into DCs, ${ }^{25}$ and blood monocytes derived from this progenitor give rise small intestine LP DCs. ${ }^{26}$ Likewise, exogenous administration of Flt3L expands the intestinal DC populations ${ }^{27}$ and may preferentially expand different DC subsets than GM-CSF. We therefore examined the effect of exogenous GM-CSF or exogenous FIt3L on the numbers of DC clusters. Administration of GM-CSF or Flt3L-Ig expanded DC populations in the LP by greater than twofold (data not shown). We did not see an increase in the numbers of $\mathrm{CD} 11 \mathrm{C}^{+}$clusters in the animals administered exogenous GM-CSF or Flt3L-Ig (Figure 4, A and $B)$. Colonization of germfree mice has been observed to increase ILF but not CP numbers. ${ }^{5,8}$ To confirm that the number of $\mathrm{CD} 11 \mathrm{C}^{+}$clusters could increase and to determine whether the numbers of $\mathrm{CD} 11 \mathrm{c}^{+}$clusters were affected by luminal microbiota, we evaluated the presence of $\mathrm{LP} \mathrm{CD}_{11 \mathrm{C}^{+}}$cells and the numbers of $\mathrm{CD}_{11 \mathrm{C}^{+}}$clusters in gnotobiotic mice colonized with normal intestinal flora. We found that germfree mice contained an LP CD11 ${ }^{+}$cell population similar to that seen in conventionalized mice (Figure 4, C and D). The number of CD11 $\mathrm{c}^{+}$clusters increased 3 weeks following conventionalization and subsequently returned to levels seen in germfree mice and specific pathogen-free housed mice 3 weeks later (Figure 4E). These observations indicate that the limiting event in the development of a $\mathrm{CD}_{11 \mathrm{C}^{+}}$cluster is unlikely cell availability, or the presence of LP CD11C ${ }^{+}$cell populations, but is a second signal or stimulus that can be delivered by luminal microbiota. In conjunction with prior observations that the numbers of CPs do not change following conventionalization of germfree mice, ${ }^{5,8}$ these observations suggest that the recruitment of DCs is an early event in the process of CPs transforming into ILFs in response to luminal microbiota.

\section{In the Absence of CXCL13, ILF Development is Arrested and Anomalous: ILF CD11C ${ }^{+}$Cells are Sources of CXCL13}

Recent studies demonstrated that B lymphocyte expression of CXCR5, the receptor for the chemokine CXCL13, is important for normal ILF development. ${ }^{18}$ Consistent with this, we found that $\mathrm{CXCL} 13^{-/-}$mice had impaired ILF development as determined by decreased numbers of $\mathrm{B}_{220^{+}}$clusters (Figure 5A). Moreover, we observed that the $\mathrm{B}^{2} 2 \mathrm{O}^{-} \mathrm{CD} 11 \mathrm{C}^{+}$cellular clusters were significantly
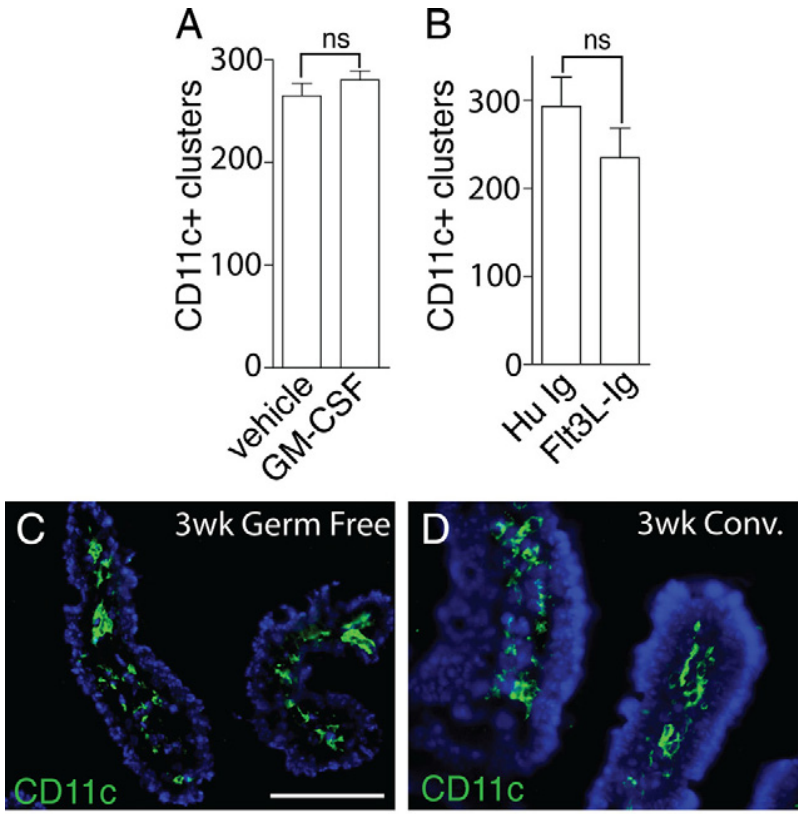

E

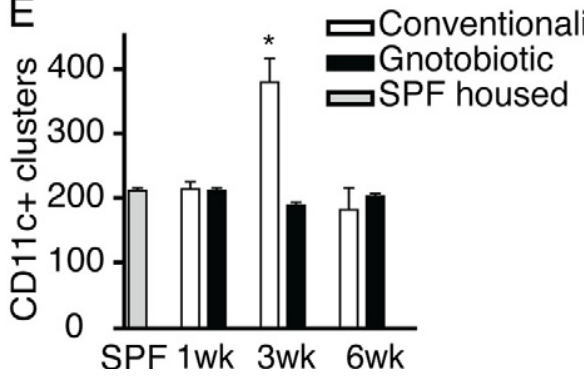

Figure 4. DC numbers are not limiting for the development of CD11c ${ }^{+}$ clusters. Cluster formation can be driven by changes in luminal microbiota. To assess the availability of DCs as a limiting factor in the development of DC clusters, we treated C57BL/ 6 mice for 2 weeks with exogenous GM-CSF or Flt3L-Ig to increase DC numbers and then evaluated the numbers of CD11 ${ }^{+}$ clusters in the intestine. Exogenous GM-CSF or Flt3L-Ig had no effect on the number of $\mathrm{CD}_{11 \mathrm{c}^{+}}$clusters $(\mathbf{A}$ and $\mathbf{B}$ ). To evaluate the role of luminal microbiota in $\mathrm{CD} 11 \mathrm{c}^{+}$cluster formation, the presence of LP DC populations and the number of clusters in the distal one-third of the intestine from gnotobiotic mice that remained germfree or their counterparts that were given cecal contents from conventionally housed $\mathrm{C} 57 \mathrm{BL} / 6$ mice were examined. Three weeks following conventionalization, the presence of the LP DC population appeared similar in germfree mice and their conventionalized counterparts ( $\mathbf{C}$ and $\mathbf{D}$ ). The numbers of $\mathrm{CD} 11 \mathrm{c}^{+}$clusters in the mice that remained germfree throughout the experiment did not change, and this was similar to the number of clusters seen in the intestine of conventionally housed $\mathrm{C} 57 \mathrm{BL} / 6$ mice $(\mathbf{E})$. Conversely the numbers of $\mathrm{CD}_{11 \mathrm{c}^{+}}$clusters increased significantly 3 weeks following colonization and returned to levels seen in specific pathogen-free housed animals germ free animals 3 weeks later (E). $n=3$ or more mice in each group and each time point. ${ }^{*} P<0.05$. Scale bar $=100 \mu \mathrm{m}$.

larger in the absence of CXCL13 (Figure 5B). In contrast to cellular clusters of similar size in wild-type mice, these large $\mathrm{CD} 11 \mathrm{C}^{+} \mathrm{B} 220^{-}$clusters in $\mathrm{CXCL} 13^{-/-}$mice do not develop a central core of mononuclear cells but instead diffuse out to engulf multiple crypts (Figure 5, C and D). These findings suggest that in the absence of CXCL13, B lymphocytes are not effectively recruited into the developing ILFs, whereas DCs can be recruited and continue to accumulate. To evaluate whether $\mathrm{CD} 11 \mathrm{c}^{+}$cells were a source of CXCL13, we isolated $\mathrm{CD}_{11 \mathrm{C}^{+}}$and $\mathrm{CD} 11 \mathrm{c}^{-}$ mononuclear cells from ILFs and evaluated CXCL13 mRNA expression. We observed that ILF CD11 ${ }^{+}$cells 
produce mRNA encoding CXCL13 (Figure 5E). To evaluate CXCL13 protein expression, we performed immunohistochemistry on whole small intestine and on isolated ILF cell populations. We observed that many cells in the ILFs were $\mathrm{CXCL} 3^{+}$(red staining; Figure 5F), and a significant number of these were $\mathrm{CD}_{11 \mathrm{C}^{+}}$(green, costaining appears yellow; Figure 5F). Insets $\mathrm{G}$ and $\mathrm{H}$ in Figure 5 demonstrate single channels for cells staining positive for both $\mathrm{CXCL} 13$ (red, inset $\mathrm{G}$ ) and $\mathrm{CD} 11 \mathrm{C}$ (green, inset H) within the ILFs. Insets I and J on Figure 5 demonstrate single channels for a cell staining positive for CXCL13 (red, inset I) and negative for CD11c (lack of green staining, inset J). To confirm positive staining for CXCL13 on ILF single-cell populations, we isolated ILF cellular populations and performed immunohistochemistry on cells affixed to slides. We observed that some
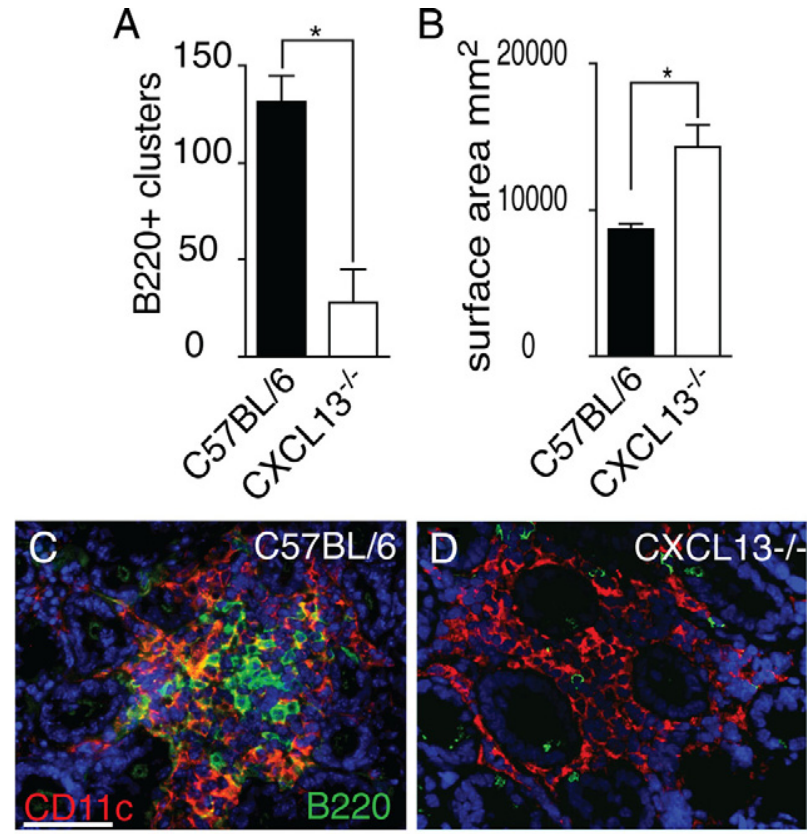

$\mathrm{E}$
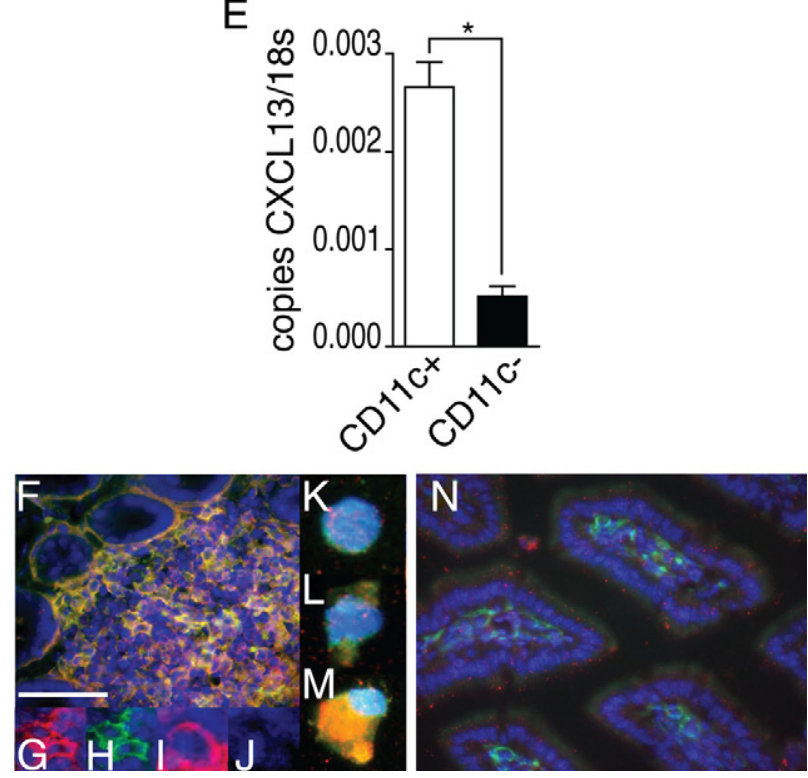

$\mathrm{CD}_{11 \mathrm{C}^{+}}$cells did not stain positive for CXCL13 (Figure 5, inset $\mathrm{K}$ and $\mathrm{L}$, green staining for CD11c only), whereas other $\mathrm{CD} 11 \mathrm{C}^{+}$cells stained positive for both $\mathrm{CD} 11 \mathrm{C}$ and CXCL13 (Figure 5, inset M, green staining for CD11C and red staining for CXCL13, costaining appears yellow). In contrast, DCs within the diffuse LP did not stain positive for CXCL13 (Figure 5N; red $=$ CXCL13, green $=$ CD11C). For comparison, real-time PCR analysis revealed that CXCL13 expression by isolated LP DC populations was $<1 / 10$ of that seen in ILF CD11 $\mathrm{C}^{+}$cells (data not shown). Thus, CXCL13 is important for the normal recruitment of B lymphocytes into ILFs, and DCs are a source of CXCL13, implying a potential function for CXCL13 production by DCs in ILF development.

\section{DCs Participate in the Maintenance of $B$ Lymphocytes in ILFS}

The hierarchical arrangement we observed between $\mathrm{CD}_{11 \mathrm{C}^{+}}$clusters and $\mathrm{B}_{220^{+}}$clusters in neonatal and adult mice is consistent with a role for DCs in recruiting and/or maintaining the B220 ${ }^{+}$cells within ILFs. To evaluate this possibility, we treated CD11C-DTR mice and their nontransgenic littermates with DT and evaluated them for the presence of LP DCs, CD11 $\mathrm{c}^{+}$cellular clusters, and $\mathrm{B}_{2} 2 \mathrm{O}^{+}$clusters. Transgenic mice treated with DT depleted their LP DC population, whereas nontransgenic animals were unchanged (data not shown). Examination for the presence of $\mathrm{B}_{2} 2 \mathrm{O}^{+}$clusters revealed significantly decreased numbers of $\mathrm{B}_{22 \mathrm{O}^{+}}$clusters in the transgenic mice when compared with nontransgenic mice treated with DT (Figure 6A). Clusters of $\mathrm{CD}^{+}{ }^{+}$cells could be easily identified in the transgenic animals following DT treatment; however, these clusters were loosely organized and contained vacant areas where $\mathrm{B}_{22}{ }^{+}$and $\mathrm{CD} 11 \mathrm{c}^{+}$cells would reside (Figure $6, \mathrm{~B}$ and

Figure 5. In the absence of CXCL13, ILF development is arrested and abnormal, and ILF CD11c ${ }^{+}$cells are sources of CXCL13. Intestines from wild-type $\mathrm{C} 57 \mathrm{BL} / 6$ mice and $\mathrm{CXCL} 13^{-1-}$ mice on the $\mathrm{C} 57 \mathrm{BL} / 6$ background were evaluated for the presence of ILFs $\left(\mathrm{B} 220^{+}\right.$clusters, $\left.\mathbf{A}\right)$ and the size (B) and morphology of the CD11 ${ }^{+}$clusters $(\mathbf{C}$ and $\mathbf{D})$. CXCL1 $3^{-/-}$mice were found to have significantly fewer ILFs (A), and conversely the surface area of the $\mathrm{B} 220^{-} \mathrm{CD} 11 \mathrm{c}^{+}$cellular clusters was found to be significantly greater in $\mathrm{CXCL}_{13} 3^{-/}$mice $(\mathbf{B})$. The $\mathrm{CD} 11 \mathrm{c}^{+} \mathrm{B} 220^{-}$clusters in the CXCL13 $3^{-/-}$intestine were of a similar size to $\mathrm{CD} 11 \mathrm{c}^{+} \mathrm{B} 220^{+}$clusters from wild-type mice but did not contain a central area filled with mononuclear cells and instead extended to engulf multiple adjacent crypts $(\mathbf{C}$ and $\mathbf{D}) . \mathrm{CD}_{11 \mathrm{c}^{+}}$and $\mathrm{CD} 11 \mathrm{c}^{-}$cellular populations were isolated from ILFs from $\mathrm{C} 57 \mathrm{BL} / 6$ mice as described in Materials and Methods, and the mRNA expression of CXCL13 was examined. CD $11 \mathrm{C}^{+}$ILF cells were found to express significantly more CXCL13 than CD11 ${ }^{-}$ILF cells (E). CXCL13 protein expression was evaluated using immunohistochemistry. CXCL13 protein (red staining, F) was detected within ILFs in the intestine of C5BL/6 mice. Many of the CXCL13-expressing cells were also $\mathrm{CD}_{11 \mathrm{c}^{+}}$(green staining, F; costaining appears yellow). Insets (G and $\mathbf{H}$ ) demonstrate individual channels for cells within ILFs costaining for both CXCL13 (red, G) and CD11c (green, H). Insets (I and J) demonstrate individual channels for cells within ILFs staining for CXCL13 (red, I) and not staining for CD11c (lack of green signal, $\mathbf{J}$ ). To confirm the results seen in whole tissues, we evaluated the protein expression of CXCL13 in isolated ILF cellular populations. ILF cells expressed CXCL13 (red signal, M) and that these cells could be CD11c ${ }^{+}$(green signal, $\mathbf{M}$; costaining appears yellow). We also observed that some CD11 $\mathrm{c}^{+}$cells (green signal, L) did not express CXCL13 (lack of red signal, $\mathbf{L}$ ), and some cells were neither $\mathrm{CD} 11 \mathrm{c}^{+}$or $\mathrm{CXCL}_{13}{ }^{+}$(lack of red and green signal, K). We did not observe CXCL13 expression by DCs located within the LP $(\mathbf{N}$ green $=$ CD11c, red $=$ CXCL13). $n=3$ intestines $\mathbf{A}$ and $\mathbf{B}$. E is representative of one of two independent experiments using pooled ILF cellular populations from three or more animals. Scale bar $=100 \mu \mathrm{m}$. ${ }^{*} P<0.05$. 
A

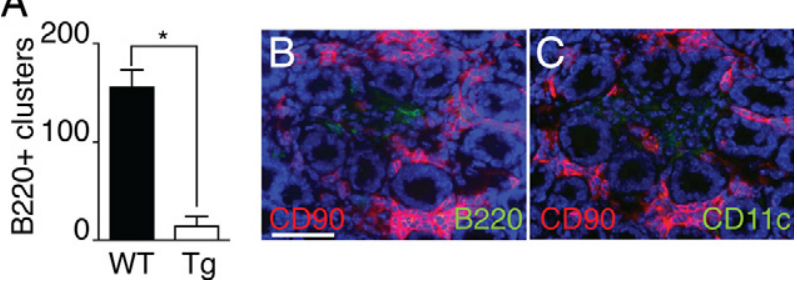

Figure 6. DCs participate in the maintenance of B lymphocytes in ILFs. To evaluate a role for CD $11 \mathrm{c}^{+}$cells in ILF maintenance CD11c-DTR transgenic mice (Tg) and wild-type C57BL/6 mice (WT) were injected with DT i.p. and evaluated for the presence of ILFs $\left(B 220^{+}\right.$clusters, A) and the morphology and the presence of $\mathrm{CD} 90^{+}, \mathrm{CD} 11 \mathrm{c}^{+}$, and $\mathrm{B} 220^{+}$cells in the SILT in the Tg animals (B and $\mathbf{C})$. Following DT treatment, B220 ${ }^{+}$clusters were maintained in WT but were significantly decreased in the transgenic animals (A). CD90 ${ }^{+}$ clusters could be easily identified in the Tg following DT treatment; however, these clusters lacked $\mathrm{CD} 11 \mathrm{c}^{+}$and $\mathrm{B} 220^{+}$cells were disorganized and engulfed the adjacent crypts (B and $\mathbf{C}$ ). $n=3$ or more animals for each condition. ${ }^{*} P<0.05$ when compared with the WT treatment group in $\mathbf{A}$ Scale bar $=100 \mu \mathrm{m}$

C). These disorganized clusters had a similar appearance to those seen in the $\mathrm{CXCL} 13^{-1-}$ mice (compare Figure 6B with Figure 5D).

\section{Discussion}

Our understanding of the contributions of both ends of the SILT continuum to innate and adaptive mucosal immunity continues to evolve. CPs were identified earlier than ILFs; ${ }^{10,11}$ however, their role in mucosal immunity is less established and their potential functions more diverse. The role of CPs in mucosal immunity centers around their principal hematopoietic cellular components, the lin $^{-}{\mathrm{C}-\mathrm{kit}^{+}}^{+}$cell. Initial investigations demonstrated that CP function as sites for the extrathymic development of $\mathrm{T}$ lymphocytes, with the in $^{-} \mathrm{c}^{-\mathrm{kit}^{+}}{ }^{+}$cells being $\mathrm{T}$ lymphocyte progenitors. ${ }^{11,28-31}$ Subsequent studies were at odds with this function, ${ }^{13}$ and the degree to which CPs contribute to extrathymic $T$ lymphocyte development in the euthymic condition is not agreed on. More recent studies demonstrate a potential role for the $\mathrm{lin}^{-} \mathrm{C}-\mathrm{kit}^{+} \mathrm{CP}$ cells as progenitors of an interleukin-22-producing NK-cell subset that promote epithelial repair. ${ }^{32-35}$ Whether the function of lin $^{-} \mathrm{c}-\mathrm{kit}^{+}$cells as progenitors for these cell types extends throughout the CP/ILF continuum is not known. Another role for the $\mathrm{lin}^{-} \mathrm{C}-\mathrm{kit}^{+} \mathrm{CP}$ cells in mucosal immunity arose from observations linking $\mathrm{CP}$ and ILFs within the SILT continuum and from studies demonstrating phenotypic and functional similarities between CP cells and fetal LTi cells. ${ }^{12}$ These observations suggest that the in $^{-} \mathrm{C}^{-\mathrm{kit}^{+}}$CPs play an integral role as initiators of lymphoid neogenesis, establishing the precursors to ILFs. ${ }^{2,13,14,36}$ ILFs contain a significant population of B lymphocytes and more developed ILFs can have germinal centers and a follicle-associated epithelium containing $M$ cells. ${ }^{7,10}$ These and subsequent findings supported a role for ILFs as sites for the induction of IgA responses to both $T$ lymphocyte-dependent and T Iymphocyte-independent antigens. ${ }^{2,3,37}$ Thus, SILT can contribute to mucosal immunity in multiple ways and potentially at multiple levels of development; however, the function as sites of $\lg A$ induction is restricted to the more developed structures in the continuum, the ILFs. Given the prominence of IgA in the maintenance of mucosal homeostasis, how CPs transition into ILFs is an important issue in understanding mucosal immunity.

In an attempt to better understand the process of CPs transitioning into ILFs, we examined the presence and timing of DC entry into the developing SILTs. DCs have been described as a cellular component of both CPs and ILFs; ${ }^{10,11}$ therefore, the existence of DC clusters in the intestine is not unexpected. Whether DC clusters existed outside of the SILT spectrum was previously unknown, and to this end, we observed that DC clusters were restricted to the SILT continuum in the normal mouse intestine. Moreover, the numerical and cell associative hierarchy we observed in the adult and neonatal intestine coupled with the chronology of different cell types forming clusters in the neonatal intestine demonstrates that the development of DC clusters occurs at a specific point in SILT continuum after the coalescence of $\mathrm{CD}^{\circ} \mathrm{O}^{+} \mathrm{c}-\mathrm{kit}^{+}$ cells, and before the influx of $\mathrm{B}$ lymphocytes. Consistent with the DC clusters occurring exclusively in the context of SILT continuum and with their chronological positioning between the $\mathrm{CD} \mathrm{O}^{+}$clusters and the $\mathrm{B}^{2} 2 \mathrm{O}^{+}$clusters was the absence of $\mathrm{CD} 11 \mathrm{c}^{+}$clusters in $\mathrm{LT} \alpha^{-/-}$mice and $\mathrm{LT} \beta \mathrm{R}^{-1-}$ mice, which lack CPs and ILFs, and the presence of $\mathrm{CD}_{11 \mathrm{C}^{+}}$clusters in mice lacking lymphocytes. Notably LP DC populations were present in $\mathrm{LT} \alpha^{-1-}$ and $\mathrm{LT} \beta \mathrm{R}^{-1-}$ mice, demonstrating differences between the presence of DCs in the LP and the development of CD11c ${ }^{+}$clusters.

We observed that the ILF CD11 $\mathrm{C}^{+}$cell population was heterogeneous and could be distinguished from that of the LP by the absence of $\mathrm{CD} 4^{+} \mathrm{CD} 11 \mathrm{c}^{+}$cells, which were common in the LP, and by the enrichment in $\mathrm{CD} 8 \alpha^{+}$ $\mathrm{CD}_{11 \mathrm{C}^{+}}$cells and $\mathrm{B} 22 \mathrm{O}^{+} \mathrm{CD} 11 \mathrm{c}^{+}$cells, which were less common in the LP. Although the phenotype of ILF DCs in comparison with LP DCs has not been previously addressed, these findings are consistent with prior observations noting differences in DC populations in different intestinal lymphoid compartments. ${ }^{38,39}$ The characteristics of the ILF CD11c ${ }^{+}$cell population could be consistent with a selective recruitment of local DC populations into the transitioning CPs. Alternatively, expansion of preexisting DCs could contribute to the formation of the $\mathrm{CD}_{11 \mathrm{c}^{+}}$clusters. Splenic DCs express the LT $\beta \mathrm{R}^{40,41}$ and signaling through the LT $\beta R$ expands and maintains splenic DC numbers. ${ }^{40,41}$ This parallels the requirement for $L T$ and the $L T \beta R$ we observed in the development of DC clusters. However, we do not favor this as the sole mechanism resulting in the accumulation of DCs in the developing ILFs, as lymphocytes were identified as the cellular source of the LT $\beta R$ ligand responsible for maintaining the homeostasis or expansion of splenic DCs, ${ }^{40,41}$ and we observed that lymphocytes are dispensable for the development of the DC clusters.

Multiple studies demonstrated an inducible nature to ILF development, with the numbers of ILFs increasing or decreasing in response to luminal stimuli. ${ }^{7-9}$ Although the dynamics of this process are incompletely understood, two simple models can be envisioned. In the first, a temporally restricted stimulus starts the cascade of 
events resulting in the development of ILFs; this model adheres to our current understanding of the dynamics of PP development, where once initiated, development proceeds and is not dependent on exogenous stimuli for progression. In the second model, temporally or phenotypically distinct stimuli are required for development of a $\mathrm{CP}$ and its progression into an ILF. Our observations and recent studies support the latter model. Pabst et al ${ }^{8}$ found that conventionalization of germfree mice resulted in no change in the numbers of structures in the CP/ILF continuum but increased the number of structures progressing to become ILFs. Extending this work Brouskra et al ${ }^{5}$ found that NOD1 ligands could promote the transition of CPs into ILFs. We found that the progression of CPS containing few DCs to CPs associated with a DC cluster was not limited by DC availability but was induced by changes in the luminal microbiota. These findings are consistent with the second model where forces driving the development of CPs are temporally or physically distinct from those resulting in the progression of CPs into ILFs. Thus, CPs could represent a reservoir of preformed nascent lymphoid tissues with the capacity to develop into IgA inductive in response to appropriate stimuli.

In comparison with their role as initiators of adaptive immune responses, the role of DCs as active participants in the development of organized lymphoid tissues is relatively unexplored. Ludewig et $\mathrm{al}^{42}$ demonstrated that repeated injections of DCs expressing an immunodominant epitope of lymphocytic choriomeningitis virus glycoprotein into transgenic mice expressing lymphocytic choriomeningitis virus glycoprotein in the pancreas resulted in the formation of organized lymphoid tissue. Marinkovic et $\mathrm{al}^{43}$ found that in transgenic mice overexpressing CCL21, T lymphocytes interact with DCs to induce the formation of ectopic lymphoid tissues, and the development of these tissues was independent of LTi-like cells. These studies suggest a role for DCs in tertiary lymphoid tissue development and imply that this role may center around their function as antigen-presenting cells in $T$ cell-dependent responses. DCs have also been observed to shape existent lymphoid tissues. DCs were found to induce endothelial cell proliferation and vascular growth in lymph nodes following immunization. ${ }^{44}$ Related studies revealed lymphatic growth in inflamed lymph nodes was dependent on B lymphocytes and that this augmented further DC migration into the inflamed lymph node. ${ }^{45}$ Somewhat in contrast to the above studies, Hashi et $\mathrm{al}^{46}$ noted $\mathrm{CD} 11 \mathrm{c}^{+}$cells enter the developing PP anlagen before mature lymphocytes, suggesting that these embryonic CD11 $\mathrm{c}^{+}$cells contribute to PP development at an early stage in a lymphocyte-independent manner. Veiga-Fernandes et al demonstrated that $\mathrm{CD} 11 \mathrm{c}^{+}$cells play an important role in PP development by delivering very early LT-dependent signals, resulting in the recruitment and coalescence of the fetal LTi cells. ${ }^{47}$ Similar to the study of Hashi et al ${ }^{46}$, we noted that $\mathrm{CD} 11 \mathrm{c}^{+}$cells accumulate after the coalescence of the $\mathrm{C}^{-\mathrm{Kit}^{+}}, \mathrm{CD}^{+}{ }^{+}, \mathrm{LTi}$-like CP cells. And in accord with a function for $\mathrm{CD}_{11 \mathrm{c}^{+}}$cells downstream of the LTi-like cells in ILF development, we found that following the loss of the $\mathrm{CD} 11 \mathrm{c}^{+}$cells, $\mathrm{B}_{22 \mathrm{O}^{+}}$ clusters are lost. Similar to the studies of Veiga-Fer- nandes et al, we observed that after the loss of CD11 $\mathrm{c}^{+}$ cells, $\mathrm{CD}^{+} \mathrm{O}^{+}$clusters become disorganized, suggesting that the $\mathrm{CD}_{11 \mathrm{c}^{+}}$cells may have a function in $\mathrm{CP}$ maintenance. However, the character of the CD11 ${ }^{+}$-dependent signal differs because Veiga-Fernandes et al found that embryonic $\mathrm{CD} 11 \mathrm{c}^{+}$cells delivered a time-restricted signal during the critical window of PP development in embryogenesis, and our findings suggest that $\mathrm{CD} 11 \mathrm{C}^{+}$ cells deliver a tonic signal facilitating ILF, and possibly $\mathrm{CP}$, maintenance. This potential role in $\mathrm{CP}$ maintenance is consistent with the findings of Suzuki et $\mathrm{al}^{31}{ }^{31}$ which demonstrated that $\mathrm{CD}_{11 \mathrm{c}^{+}}$cells inhabit CPs before c$\mathrm{kit}^{+}$cells following irradiation and bone marrow reconstitution in athymic mice with a truncation of the common cytokine receptor $\gamma$ chain.

Because of its constitutive expression in lymphoid tissues and its established role directing the normal segregation of lymphocytes and the organization of follicles, CXCL13 is often characterized as a "homeostatic" chemokine. However, several lines of evidence implicate an additional role for CXCL13 in the development of lymphoid tissues. CXCL13 and its receptor CXCR5 play important roles in the formation of intestinal lymphoid tissues documented by impaired PP development in mice deficient in either CXCL13 or CXCR5. ${ }^{48,49}$ In this context, CXCL13 produced by stromal cells functions to activate and coalesce CXCR5-expressing fetal LTi cells during embryogenesis initiating PP development, and CXCR5 expression by $\mathrm{B}$ lymphocytes is required for their localization to PP. Further investigations indicate that CXCL13 can participate in the de novo formation of lymphoid tissues. CXCL13 is highly expressed at the sites of new lymphoid tissue formation in a variety of chronic inflammatory conditions, ${ }^{50-57}$ and ectopic expression of CXCL13 in a transgenic mouse model resulted in the formation of new extranodal lymphoid tissues. ${ }^{58}$ In further support of a role for $\mathrm{CXCL} 13$ in lymphoid tissue development and consistent with our observations, CXCR5 participates in SILT development at an early stage when the LTi-like cells cluster to form CPs and at a later stage when B lymphocytes are recruited into the developing follicle. ${ }^{18}$ Therefore, multiple lines of investigation indicate that CXCL13 can play an important role in the development of a wide range of lymphoid tissues.

CXCL13 production within lymphoid tissues has largely been attributed to follicular DCs residing within germinal centers; however, consistent with our observations, several studies identified $\mathrm{CD}_{11 \mathrm{c}^{+}}$cells as additional sources of CXCL13. CXCL13 expression localized to structures described as peripheral dendritic elements in lymphoid tissues in the normal intestine and in aberrant lymphoid tissues formed in ulcerative colitis. ${ }^{51}$ Further investigations localized the CXCL13 expression in the aberrant lymphoid tissues to $\mathrm{CD} 11 \mathrm{c}^{+}$cells. ${ }^{59}$ Moreover, in the above study, the CXCL13 production by $\mathrm{CD}_{11 \mathrm{C}^{+}}$ cells in intestinal lymphoid aggregates was present in small aggregates lacking a germinal center, ${ }^{59}$ further indicating that follicular DCs are unlikely the source of CXCL13 in this situation. Additional support for intestinal DCs production of CXCL13 comes from in vitro studies demonstrating CXCL13 expression by DCs following 
stimulation with interleukin-10 and lipopolysaccharide; 60 stimuli that could be commonly encountered in the intestine. We observed that ILF DCs could express CXCL13. However, DCs were not the sole source of CXCL13 within the ILFs, because we also found $\mathrm{CXCL} 13^{+}$cells that were $\mathrm{CD} 11 \mathrm{c}^{-}$within ILFs when evaluating whole tissues. The $\mathrm{CXCL} 13^{+} \mathrm{CD} 11 \mathrm{C}^{-}$cells were uncommon when we evaluated the isolated ILF cell populations, which could relate to the isolation technique, or to the preferential adherence of cell types to the slide substrate.

Our understanding of the mucosal immune system's strategies to maintain homeostasis at a large environmentally exposed surface continues to grow. Among these are the recently appreciated diverse functions of CPs and ILFs, including their ability to generate novel lymphocyte subsets and to act as sites for the induction of T cell-dependent and T cell-independent IgA., 2,32-35 The observations presented here add to this list by demonstrating an unappreciated role for DCs expressing $\mathrm{CXCL} 13$ and promoting the transition of CPs into ILFs. These observations suggest that like other cellular components of SILTs, DCs perform dual functions by shaping their microenvironment and generating immune responses.

\section{Acknowledgments}

We thank the Alvin J. Siteman Cancer Center (Washington University School of Medicine and Barnes-Jewish Hospital in St. Louis, MO) for the use of the High-Speed Cell Sorter Core, which provided flow cytometry services. We thank the Washington University School of Medicine Digestive Diseases Research Core Center for assistance with morphology services and gnotobiotic mice.

\section{References}

1. Macpherson AJ, McCoy KD, Johansen FE, Brandtzaeg P: The immune geography of IgA induction and function. Mucosal Immunol 2008, 1:11-22

2. Tsuji M, Suzuki K, Kitamura H, Maruya M, Kinoshita K, Ivanov II, Itoh K, Littman DR, Fagarasan S: Requirement for lymphoid tissue-inducer cells in isolated follicle formation and T cell-independent immunoglobulin A generation in the gut. Immunity 2008, 29:261-271

3. Lorenz RG, Newberry RD: Isolated lymphoid follicles can function as sites for induction of mucosal immune responses. Ann NY Acad Sci 2004, 1029:44-57

4. Herbrand H, Bernhardt G, Forster R, Pabst O: Dynamics and function of solitary intestinal lymphoid tissue. Crit Rev Immunol 2008, 28:1-13

5. Bouskra D, Brezillon C, Berard M, Werts C, Varona R, Boneca IG, Eberl G: Lymphoid tissue genesis induced by commensals through NOD1 regulates intestinal homeostasis. Nature 2008, 456:507-510

6. Kweon MN, Yamamoto M, Rennert PD, Park EJ, Lee AY, Chang SY, Hiroi T, Nanno M, Kiyono $\mathrm{H}$ : Prenatal blockage of lymphotoxin $\beta$ receptor and TNF receptor p55 signaling cascade resulted in the acceleration of tissue genesis for isolated lymphoid follicles in the large intestine. J Immunol 2005, 174:4365-4372

7. Lorenz RG, Chaplin DD, McDonald KG, McDonough JS, Newberry RD: Isolated lymphoid follicle formation is inducible and dependent upon lymphotoxin-sufficient $B$ lymphocytes, lymphotoxin $\beta$ receptor, and TNF receptor I function. J Immunol 2003, 170:5475-5482

8. Pabst $\mathrm{O}$, Herbrand $\mathrm{H}$, Friedrichsen M, Velaga S, Dorsch M, Berhardt G, Worbs T, Macpherson AJ, Forster R: Adaptation of solitary intes- tinal lymphoid tissue in response to microbiota and chemokine receptor CCR7 signaling. J Immunol 2006, 177:6824-6832

9. Suzuki K, Meek B, Doi Y, Muramatsu M, Chiba T, Honjo T, Fagarasan $\mathrm{S}$ : Aberrant expansion of segmented filamentous bacteria in IgAdeficient gut. Proc Natl Acad Sci USA 2004, 101:1981-1986

10. Hamada H, Hiroi $T$, Nishiyama $Y$, Takahashi H, Masunaga $Y$, Hachimura S, Kaminogawa S, Takahashi-Iwanaga $H$, Iwanaga $T$, Kiyono $\mathrm{H}$, Yamamoto $\mathrm{H}$, Ishikawa $\mathrm{H}$ : Identification of multiple isolated lymphoid follicles on the antimesenteric wall of the mouse small intestine. J Immunol 2002, 168:57-64

11. Kanamori $\mathrm{Y}$, Ishimaru K, Nanno M, Maki K, Ikuta K, Nariuchi H, Ishikawa $\mathrm{H}$ : Identification of novel lymphoid tissues in murine intestinal mucosa where clusters of c-kit ${ }^{+} \mathrm{LL}-7 \mathrm{R}^{+} \mathrm{Thy} 1^{+}$Iympho-hemopoietic progenitors develop. J Exp Med 1996, 184:1449-1459

12. Eberl G: Inducible lymphoid tissues in the adult gut: recapitulation of a fetal developmental pathway? Nat Rev Immunol 2005, 5:413-420

13. Eberl G, Littman DR: Thymic origin of intestinal $\alpha \beta$ T cells revealed by fate mapping of ROR $\gamma \mathrm{t}^{+}$cells. Science 2004, 305:248-251

14. Eberl G, Marmon S, Sunshine MJ, Rennert PD, Choi Y, Littman DR: An essential function for the nuclear receptor $\mathrm{ROR} \gamma(\mathrm{t})$ in the generation of fetal Iymphoid tissue inducer cells. Nat Immunol 2004, 5:64-73

15. McDonald KG, McDonough JS, Newberry RD: Adaptive immune responses are dispensable for isolated lymphoid follicle formation: antigen-naive, lymphotoxin-sufficient B lymphocytes drive the formation of mature isolated lymphoid follicles. J Immunol 2005, 174:5720-5728

16. McDonald KG, McDonough JS, Wang C, Kucharzik T, Williams IR, Newberry RD: CC Chemokine receptor 6 expression by B lymphocytes is essential for the development of isolated lymphoid follicles. Am J Pathol 2007, 170:1229-1240

17. Wang C, McDonough JS, McDonald KG, Huang C, Newberry RD: $\alpha_{4} \beta_{7} / \mathrm{MAdCAM}-1$ interactions play an essential role in transitioning cryptopatches into isolated lymphoid follicles and a nonessential role in cryptopatch formation. J Immunol 2008, 181:4052-4061

18. Velaga S, Herbrand H, Friedrichsen M, Jiong T, Dorsch M, Hoffmann MW, Forster R, Pabst O: Chemokine receptor CXCR5 supports solitary intestinal lymphoid tissue formation. B cell homing, and induction of intestinal IgA responses. J Immunol 2009, 182:2610-2619

19. Newberry RD, McDonough JS, McDonald KG, Lorenz RG: Postgestational lymphotoxin/lymphotoxin $\beta$ receptor interactions are essential for the presence of intestinal B lymphocytes. J Immunol 2002, 168:4988-4997

20. Sainathan SK, Tu L, Bishnupuri KS, Han M, Li A, Newberry RD, McDonald KG, Crimmins DL, Houchen C, Anant S, Dieckgraefe BK: PEGylated murine granulocyte-macrophage colony-stimulating factor: production, purification, and characterization. Protein Expr Purif 2005, 44:94-103

21. Blasius A, Vermi W, Krug A, Facchetti F, Cella M, Colonna M: A cell-surface molecule selectively expressed on murine natural interferon-producing cells that blocks secretion of interferon- $\alpha$. Blood 2004, 103:4201-4206

22. Metlay JP, Witmer-Pack MD, Agger R, Crowley MT, Lawless D, Steinman RM: The distinct leukocyte integrins of mouse spleen dendritic cells as identified with new hamster monoclonal antibodies. J Exp Med 1990, 171:1753-1771

23. Taylor RT, Lugering A, Newell KA, Williams IR: Intestinal cryptopatch formation in mice requires lymphotoxin $\alpha$ and the lymphotoxin $\beta$ receptor. J Immunol 2004, 173:7183-7189

24. Wu L, Dakic A: Development of dendritic cell system. Cell Mol Immunol 2004, 1:112-118

25. Fogg DK, Sibon C, Miled C, Jung S, Aucouturier P, Littman DR, Cumano A, Geissmann F: A clonogenic bone marrow progenitor specific for macrophages and dendritic cells. Science 2006, 311: 83-87

26. Varol C, Landsman L, Fogg DK, Greenshtein L, Gildor B, Margalit R, Kalchenko V, Geissmann F, Jung S: Monocytes give rise to mucosal, but not splenic, conventional dendritic cells. J Exp Med 2007, 204:171-180

27. Viney JL, Mowat AM, O'Malley JM, Williamson E, Fanger NA: Expanding dendritic cells in vivo enhances the induction of oral tolerance. J Immunol 1998, 160:5815-5825

28. Oida T, Suzuki K, Nanno M, Kanamori Y, Saito H, Kubota E, Kato S, Itoh M, Kaminogawa S, Ishikawa H: Role of gut cryptopatches in early extrathymic maturation of intestinal intraepithelial T cells. J Immunol 2000, 164:3616-3626 
29. Onai N, Kitabatake M, Zhang YY, Ishikawa H, Ishikawa S, Matsushima K: Pivotal role of CCL25 (TECK)-CCR9 in the formation of gut cryptopatches and consequent appearance of intestinal intraepithelial T lymphocytes. Int Immunol 2002, 14:687-694

30. Saito H, Kanamori Y, Takemori T, Nariuchi H, Kubota E, TakahashiIwanaga $\mathrm{H}$, Iwanaga $\mathrm{T}$, Ishikawa $\mathrm{H}$ : Generation of intestinal T cells from progenitors residing in gut cryptopatches. Science 1998, 280:275-278

31. Suzuki K, Oida T, Hamada H, Hitotsumatsu O, Watanabe M, Hibi T, Yamamoto H, Kubota E, Kaminogawa S, Ishikawa H: Gut cryptopatches: direct evidence of extrathymic anatomical sites for intestinal T Iymphopoiesis. Immunity 2000, 13:691-702

32. Cella M, Fuchs A, Vermi W, Facchetti F, Otero K, Lennerz JK, Doherty JM, Mills JC, Colonna M: A human natural killer cell subset provides an innate source of IL-22 for mucosal immunity. Nature 2009, 457:722-725

33. Satoh-Takayama N, Vosshenrich CA, Lesjean-Pottier S, Sawa S, Lochner M, Rattis F, Mention JJ, Thiam K, Cerf-Bensussan N, Mandelboim O, Eberl G, Di Santo JP: Microbial flora drives interleukin 22 production in intestinal $\mathrm{NKp}^{+} 6^{+}$cells that provide innate mucosal immune defense. Immunity 2008, 29:958-970

34. Vivier E, Spits H, Cupedo T: Interleukin-22-producing innate immune cells: new players in mucosal immunity and tissue repair? Nat Rev Immunol 2009, 9:229-234

35. Cupedo T, Crellin NK, Papazian N, Rombouts EJ, Weijer K, Grogan JL, Fibbe WE, Cornelissen JJ, Spits H: Human fetal lymphoid tissueinducer cells are interleukin 17-producing precursors to RORC ${ }^{+}$ $\mathrm{CD}_{127^{+}}$natural killer-like cells. Nat Immunol 2009, 10:66-74

36. Pabst O, Herbrand H, Worbs T, Friedrichsen M, Yan S, Hoffmann MW, Korner H, Bernhardt G, Pabst R, Forster R: Cryptopatches and isolated lymphoid follicles: dynamic lymphoid tissues dispensable for the generation of intraepithelial lymphocytes. Eur J Immunol 2005, 35:98-107

37. Wang $C$, McDonald KG, McDonough JS, Newberry RD: Murine isolated lymphoid follicles contain follicular B-lymphocytes with a mucosal phenotype. Am J Physiol Gastrointest Liver Physiol 2006, 291:G595-G604

38. Niess JH, Brand S, Gu X, Landsman L, Jung S, McCormick BA, Vyas JM, Boes M, Ploegh HL, Fox JG, Littman DR, Reinecker HC: CX3CR1mediated dendritic cell access to the intestinal lumen and bacterial clearance. Science 2005, 307:254-258

39. Salazar-Gonzalez RM, Niess JH, Zammit DJ, Ravindran R, Srinivasan A, Maxwell JR, Stoklasek T, Yadav R, Williams IR, Gu X, McCormick BA, Pazos MA, Vella AT, Lefrancois L, Reinecker HC, McSorley SJ: CCR6-mediated dendritic cell activation of pathogen-specific T cells in Peyer's patches. Immunity 2006, 24:623-632

40. Kabashima K, Banks TA, Ansel KM, Lu TT, Ware CF, Cyster JG: Intrinsic lymphotoxin- $\beta$ receptor requirement for homeostasis of lymphoid tissue dendritic cells. Immunity 2005, 22:439-450

41. Wang YG, Kim KD, Wang J, Yu P, Fu YX: Stimulating lymphotoxin $\beta$ receptor on the dendritic cells is critical for their homeostasis and expansion. J Immunol 2005, 175:6997-7002

42. Ludewig B, Odermatt B, Landmann S, Hengartner H, Zinkernagel RM: Dendritic cells induce autoimmune diabetes and maintain disease via de novo formation of local lymphoid tissue. J Exp Med 1998, 188:1493-1501

43. Marinkovic T, Garin A, Yokota Y, Fu YX, Ruddle NH, Furtado GC, Lira $\mathrm{SA}$ : Interaction of mature $\mathrm{CD}^{+} \mathrm{CD}^{+}{ }^{+} \mathrm{T}$ cells with dendritic cells triggers the development of tertiary lymphoid structures in the thyroid J Clin Invest 2006, 116:2622-2632

44. Webster B, Ekland EH, Agle LM, Chyou S, Ruggieri R, Lu TT: Regulation of lymph node vascular growth by dendritic cells. J Exp Med 2006, 203:1903-1913

45. Angeli V, Ginhoux F, Llodra J, Quemeneur L, Frenette PS, Skobe M, Jessberger R, Merad M, Randolph GJ: B cell-driven lymphangiogenesis in inflamed lymph nodes enhances dendritic cell mobilization. Immunity 2006, 24:203-215
46. Hashi H, Yoshida H, Honda K, Fraser S, Kubo H, Awane M, Takabayashi A, Nakano H, Yamaoka Y, Nishikawa SI: Compartmentalization of Peyer's patch anlagen before lymphocyte entry. J Immunol 2001, 166:3702-3709

47. Veiga-Fernandes $\mathrm{H}$, Coles MC, Foster KE, Patel A, Williams A, Natarajan D, Barlow A, Pachnis V, Kioussis D: Tyrosine kinase receptor RET is a key regulator of Peyer's patch organogenesis, Nature 2007. 446:547-551

48. Forster R, Mattis AE, Kremmer E, Wolf E, Brem G, Lipp M: A putative chemokine receptor, BLR1, directs $B$ cell migration to defined lymphoid organs and specific anatomic compartments of the spleen. Cell 1996, 87:1037-1047

49. Ansel KM, Ngo VN, Hyman PL, Luther SA, Forster R, Sedgwick JD, Browning JL, Lipp M, Cyster JG: A chemokine-driven positive feedback loop organizes lymphoid follicles. Nature 2000, 406:309-314

50. Barone F, Bombardieri M, Manzo A, Blades MC, Morgan PR, Challacombe SJ, Valesini G, Pitzalis C: Association of CXCL13 and CCL21 expression with the progressive organization of lymphoid-like structures in Sjogren's syndrome. Arthritis Rheum 2005, 52:1773-1784

51. Carlsen HS, Baekkevold ES, Johansen FE, Haraldsen G, Brandtzaeg P: B cell attracting chemokine 1 (CXCL13) and its receptor CXCR5 are expressed in normal and aberrant gut associated lymphoid tissue. Gut 2002, 51:364-371

52. Manzo A, Paoletti S, Carulli M, Blades MC, Barone F, Yanni G, Fitzgerald O, Bresnihan B, Caporali R, Montecucco C, Uguccioni M, Pitzalis C: Systematic microanatomical analysis of CXCL13 and CCL21 in situ production and progressive lymphoid organization in rheumatoid synovitis. Eur J Immunol 2005, 35:1347-1359

53. Moyron-Quiroz JE, Rangel-Moreno J, Kusser K, Hartson L, Spraque F, Goodrich S, Woodland DL, Lund FE, Randall TD: Role of inducible bronchus associated lymphoid tissue (BALT) in respiratory immunity. Nat Med 2004, 10:927-934

54. Salomonsson S, Larsson P, Tengner P, Mellquist E, Hjelmstrom P, Wahren-Herlenius $\mathrm{M}$ : Expression of the $\mathrm{B}$ cell-attracting chemokine CXCL13 in the target organ and autoantibody production in ectopic lymphoid tissue in the chronic inflammatory disease Sjogren's syndrome. Scand J Immunol 2002, 55:336-342

55. Shi K, Hayashida K, Kaneko M, Hashimoto J, Tomita T, Lipsky PE, Yoshikawa H, Ochi T: Lymphoid chemokine B cell-attracting chemokine-1 (CXCL13) is expressed in germinal center of ectopic lymphoid follicles within the synovium of chronic arthritis patients. J Immunol 2001, 166:650-655

56. Shomer NH, Fox JG, Juedes AE, Ruddle NH, Drayton DL, Ying X, Lee J, Lesslauer W: Helicobacter-induced chronic active lymphoid aggregates have characteristics of tertiary lymphoid tissue ectopic LT $\alpha$ $\beta$ directs lymphoid organ neogenesis with concomitant expression of peripheral node addressin and a HEV-restricted sulfotransferase, Infect Immun 2003, 71:3572-3577

57. Takemura S, Braun A, Crowson C, Kurtin PJ, Cofield RH, O'Fallon WM, Goronzy JJ, Weyand CM: Lymphoid neogenesis in rheumatoid synovitis. J Immunol 2001, 167:1072-1080

58. Luther SA, Lopez T, Bai W, Hanahan D, Cyster JG: BLC expression in pancreatic islets causes $B$ cell recruitment and lymphotoxin-dependent lymphoid neogenesis. Immunity 2000, 12:471-481

59. Carlsen HS, Baekkevold ES, Morton HC, Haraldsen G, Brandtzaeg P. Monocyte-like and mature macrophages produce CXCL13 (B cellattracting chemokine 1) in inflammatory lesions with lymphoid neogenesis. Blood 2004, 104:3021-3027

60. Perrier P, Martinez FO, Locati M, Bianchi G, Nebuloni M, Vago G Bazzoni F, Sozzani S, Allavena P, Mantovani A: Distinct transcriptional programs activated by interleukin-10 with or without lipopolysaccharide in dendritic cells: induction of the B cell-activating chemokine, CXC chemokine ligand 13. J Immunol 2004, 172: 7031-7042 